\title{
Oxygen-dependent Radiosensitivity of Escherichia coli and Mitigation in Lethality by Superoxide Dismutase
}

\author{
Taeko Niwa, Hikoyuki YamaguCHI and Keiji YANO ${ }^{\dagger}$ \\ Radiation Microbiology, Faculty of Agriculture, The University of Tokyo, Tokyo 113 \\ ${ }^{*}$ Radiation Genetics, Faculty of Agriculture, The University of Tokyo, Tokyo 113
}

Received June 30, 1977

\begin{abstract}
Oxygen-dependent radiosensitivity of Escherichia coli W3623 his was confirmed. Regarding cellular superoxide dismutase (SOD), cells grown oxically gained higher activity than those grown anoxically, however, the reinforced enzyme level could not compensate the oxygen effect, i.e., the enhanced lethal effect of oxic r-irradiation. Rather, the enhancement of oxygen effect was found in cells grown oxically compared with those anoxically. Oxygen enhanced lethality was mitigated to the extent by the amount of added SOD into the cell suspension to be irradiated. The results supported a proposal that superoxide anion, $\mathrm{O}_{2}^{-}$, is involved in the oxygen effect, with the most likely site of the damage in the outer structure of cell but not in the cell matrix. Reverse oxygen effect could be found with $\lambda$ phage DNA in transfecting ability. Added SOD protected phage DNA somewhat in oxic irradiation. While considerable protections were found in anoxic one with the added SOD even autoclaved but their function was still unknown.
\end{abstract}

The presence of molecular oxygen during $\gamma$ - or X-rays irradiation inevitably enhances the radiosensitivity of the cell in every type. The mechanism of this universal phenomenon, the so called oxygen effect, has been suggested to involve very fast free-radical reactions but the further has been unclear. Recently, a great attention has rapidly focused on oxygen toxicity in both biological and medical viewpoints. Fridovich and his colleagues have pointed out that superoxide anion, $\mathrm{O}_{2}^{-}$, is toxic to bacterial cells and that an enzyme superoxide dismutase (SOD, EC 1.15.1.1) can specifically scavenge this radical anion leading to the rescue of cells. ${ }^{1 \text { ) }}$. The reinforced level of cellular SOD which is induced by the higher oxygen tension contributes the survival of several species of bacterial cells under the hyperbaric oxygen. ${ }^{2 \sim 4)}$ However, Goscin and Fridovich reported that the high level of this intracellular enzyme could not contribute to reduce the oxygen effect of ionizing irradiation. $^{51}$

+ To whom correspondence should be adressed. Abbreviations used: OER, oxygen enhancement ratio; SOD, superoxide dismutase.
On the other hand, Hollaender and his colleagues have reported that aerobically grown cells exhibited more susceptibility to the oxygen enhanced lethality than anoxically grown cells. ${ }^{6}$ ) This fact has so far attracted less attention.

On the contrary, the extracellular presence of SOD which is addea into a cell suspension mitigates the enhanced lethal effect of aerobic irradiation in Acholeplasma lailawii having fairly low level of cellular SOD. ${ }^{7}$ Since then, the radioprotective effect of SOD has been discussed in a model membrane ${ }^{8)}$ and others. Superoxide anion generated inside cell may be removed more or less by SOD in situ. The question arises whether the cellular SOD could protect cells surely enough from the attack of $\mathrm{O}_{2}^{-}$which is generated outside cell. $A$ recent review discusses in such a view-point. ${ }^{9}$ ?

This paper deals with the oxygen-dependent radiosensitivity of Escherichia coli W3623 his ${ }^{-}$ cells grown under different oxygen tensions with a special reference to the radioprotective effect of SOD which was added into the cell suspension to be irradiated. The case of $\lambda$ phage DNA is also described. 


\section{MATERIALS AND METHODS}

Strains used. Escherichia coli $\mathrm{W} 3623 \mathrm{his}^{-}$( $\mathrm{gal}_{\text {s }}$ his, trp, st $r-r)$ and $E$. coli C600S were kindly supplied by H. Ozeki, Kyoto University, Kyoto, bacteriophage acI (clear mutant) as well.

Growth conditions. E. coli W3623 his ${ }^{-}$cells were inoculated to $10 \mathrm{ml}$ of Davis's minimal medium without thiamine and supplemented with appropriate amino acids in a Monod's tube which could be sealed hermetically with a rubberstopper equipped with a glass cock. The tubes were saturated with 1 atm of $\mathrm{O}_{2}$ or $\mathrm{N}_{2}$ by flush and evacuation after inoculation except for those with air. Culture was done overnight at $33^{\circ} \mathrm{C}$ with gently shaking. Bacterial growth was monitored photometrically at $660 \mathrm{~nm}$. Harvested cells were suspended into $67 \mathrm{~mm}$ phosphate buffer $\mathrm{pH} 7.2$ at the concentration of $1 \sim 2 \times 10^{7}$ cells $/ \mathrm{ml}$. A portion of $0.6 \mathrm{ml}$ of this suspension was poured into a glass test tube which could be sealed up as the similar manner as a Monod's tube mentioned above. Three different atmospheric conditions, 1 atm of $\mathrm{O}_{2}$, air, and $\mathrm{N}_{2}$ were settled inside the tubes. These tubes were subjected to $\gamma$-irradiation.

Surviving colonies of bacteria were enumerated on TGY-agar plates cultured at $37^{\circ} \mathrm{C}$ in the usual manner. Irradiated cell suspension was appropriately diluted with the buffer and $0.1 \mathrm{ml}$ of resulting suspension was plated on a solidified medium with the aid of a glass spreader. Plating was done within $1 \mathrm{hr}$ after irradiation. Triplicated plates for each dilution were applied.

Phage DNA. $\lambda c \mathrm{I}$ phage which was propagated in $E$. coli $\mathrm{C} 600 \mathrm{~S}$ host cells on $\lambda$ agar medium (Bactotryptone, $10 \mathrm{~g} ; \mathrm{NaCl}, 2.5 \mathrm{~g}$; agar $1.2 \mathrm{~g}$ per liter) was collected by the usual plate lysating method and purified by ultracentrifugation in a $\mathrm{CsCl}$ density gradient. DNA extracted with phenol was suspended into $3 \times \mathrm{SSC}$ $\left(0.45 \mathrm{M} \mathrm{NaCl}, 0.045 \mathrm{M} \mathrm{Na}_{3}\right.$-citrate) in the concentration of $5 \mu \mathrm{g} / \mathrm{ml}$. An open-circular molecule of $\lambda$ DNA was obtained by heating at $75^{\circ} \mathrm{C}$ for $10 \mathrm{~min}$ followed by gradual cooling. ${ }^{10}$ After dialysis against $10 \mathrm{~mm}$ phosphate buffer $\mathrm{pH} 6.2,0.3 \mathrm{ml}$ of the suspension was poured into the glass test tube for irradiation as mentioned before. The atmospheric condition inside the tubes was the same as those of bacteria.

Transfection. One-tenth volume of $10 \times$ SSC $(1.5 \mathrm{M}$ $\mathrm{NaCl}, 0.15 \mathrm{M} \mathrm{Na}_{3}$-citrate) was added to a DNA sample. This procedure developed up to 5 to 10 times higher in transfecting ability. Transfection was conducted according to the method of Mandel and Higa. ${ }^{11)}$ The recipient was E. coli C600S grown in P-medium, ${ }_{2}^{12}$ supplemented with $10 \mathrm{mg}$ of tryptophan and $10 \mathrm{ml}$ of $10 \%$ casamino acid per 1 liter, at $37^{\circ} \mathrm{C}$ with gently shaking. Indicator strain was also $E$. coli $\mathrm{C} 600 \mathrm{~S}$ grown in $\lambda$-broth (Bacto-tryptone, $10 \mathrm{~g} ; \mathrm{NaCl}, 2.5 \mathrm{~g}$ per liter) overnight at $37^{\circ} \mathrm{C}$. The mixture consisting of $0.2 \mathrm{ml}$ of transfected sample, $0.1 \mathrm{ml}$ of indicator strain culture and $2.5 \mathrm{ml}$ of molton agar $(0.45 \%$ was spreaded on $\lambda$-agar. Plaque number was scored after incubation at $37^{\circ} \mathrm{C}$.

Irradiation. A ${ }^{60} \mathrm{Co}$ irradiator of The Research Center of Nuclear Science and Technology, The University of Tokyo, was used at room temperature. Dose rate applied was $9.7 \times 10^{2} \mathrm{rad} / \mathrm{min}$.

SOD. Two purified SOD preparations from spinach were kindly gifted by K. Asada, Kyoto University, Uji. Crystalline SOD $(9300 \mathrm{U} / \mathrm{mg})$ was used in the experiment of $E$. coli. A highly purified preparation $(8500 \mathrm{U} / \mathrm{mg}$ ) was used in that of $\lambda$ phage DNA. The former was dissolved in $67 \mathrm{~mm}$ phosphate buffer pH 7.2 and the latter in $10 \mathrm{~mm}$ phosphate buffer pH 6.2. Both enzyme solutions were dialyzed against each buffer followed by membrane filtration $(0.45 \mu)$ for disinfection. SOD activity was determined according to the method of Asada et al. ${ }^{13)}$

Others. Cell-free extract of E. coli W3623 his - was obtained by sonication, $10 \mathrm{kc} 50 \mathrm{w}$ for $10 \mathrm{~min}$, followed by centrifugation at $10,000 \times g$ for $30 \mathrm{~min}$. Protein content was calculated from the absorbance at $280 \mathrm{~nm}$, $E_{1 \mathrm{~cm}}(c=1 \%)=10.0 .{ }^{14)} \quad$ Catalase, xanthine oxidase and cytochrome $c$ were purchased from Boehringer Mannheim $\mathrm{GmbH}$.

\section{RESULTS}

Oxygen enhancement ratio for $E$. coli cells grown under different oxygen tensions

The radiosensitivity of $E$. coli cells grown under three different oxygen tensions, $1 \mathrm{~atm}$ of $\mathrm{O}_{2}$, air, and $\mathrm{N}_{2}$, is depicted in Fig. 1A and B. In anoxic irradiation $\left(\mathrm{N}_{2}\right.$; broken line in Fig. 1A), all cell samples showed little difference in radiosensitivity one another. In the irradiation in the presence of oxygen $\left(\mathrm{O}_{3}\right.$ : solid lines in Fig. 1A, air: solid lines in Fig. 1B), oxygen enhanced lethal effect was clear in all samples. Moreover, the higher tension of oxygen during cell growth, the higher radiosensitivity. Seven independent experiments drew the same conclusion. The value of oxygen enhancement ratio (OER) was calculated from the slopes of a linear portion of survival curves (OER = $\mathrm{S}_{\mathrm{O}_{2}} / \mathrm{S}_{\mathrm{N}_{2}}$ ) and is shown in Table I together with cellular SOD level in three cell samples. The data obtained here indicated that SOD is 


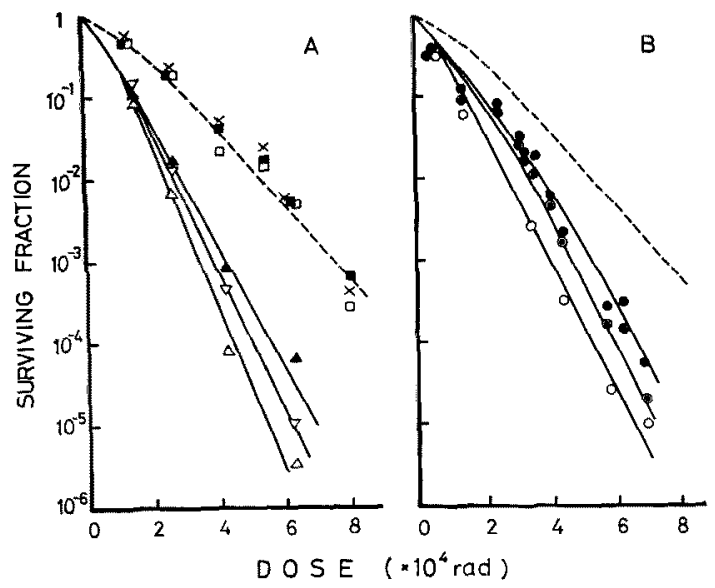

Fig. 1. Survival Curves of $E$. coli Cells Irradiated under Oxic or Anoxic Condition.

E. coli W3623 his- cells grown under 1 atm of $\mathrm{O}_{2}$, of air or of $\mathrm{N}_{2}$ were irradiated with $\gamma$-rays under 1 atm of $\mathrm{O}_{2}$ of air or of $\mathrm{N}_{2}$. A) Under $\mathrm{O}_{2}$ and $\mathrm{N}_{2}$ irradiations. Broken line: all three cell samples irradiated in $\mathrm{N}_{2} ; \mathbf{v}$, cells grown in $\mathrm{N}_{2} ; \times$, in air; $\square$, in $\mathrm{O}_{2}$. Solid lines: irradiated in $\mathrm{O}_{2} ; \Delta$, cells grown in $\mathrm{N}_{2} ; \nabla$, in air; $\Delta$, in $\mathrm{O}_{2}$. B) Under normal air and $\mathrm{N}_{2}$ irradiations. Broken line: the same as in A). Solid lines: irradiated in normal air, cells grown in $\mathrm{N}_{2} ; \odot$, in air; $\mathrm{O}$, in $\mathrm{O}_{2}$. Details are in MAterials AND METHODS.

Table I. OER ${ }^{a}$ Values and Cellular SOD OF E. coli Cells GROWN UNDER DifFerent OXYGen TeNSION

\begin{tabular}{ccc}
$\begin{array}{c}\text { Growth condition } \\
\text { under }\end{array}$ & OER $^{a}$ & $\begin{array}{c}\text { SOD } \\
\text { (U/mg protein) }\end{array}$ \\
\hline $1 \mathrm{~atm}$ of $\mathrm{N}_{2}$ & 1.8 & 0.39 \\
$1 \mathrm{~atm}$ of air & 1.9 & 0.96 \\
$1 \mathrm{~atm}$ of $\mathrm{O}_{2}$ & 2.0 & 3.86 \\
\hline
\end{tabular}

a Oxygen enhancement ratio was calculated from the following equation:

$\mathrm{OER}=\mathrm{S}_{\mathrm{O}_{2}} / \mathrm{S}_{\mathrm{N}_{2}}$

in which $\mathrm{S}_{\mathrm{O}_{2}}$ stands for slope of survival curves in oxic irradiation $\left(\mathrm{O}_{2}\right)$ and $\mathrm{S}_{\mathrm{N}_{2}}$ stands for that in anoxic irradiation $\left(\mathrm{N}_{2}\right)$. Details are in Materials AND Methods.

inducible in the cells of E. coli W3623 his ${ }^{-}$, a derivative of $\mathrm{K}-12$ strain, by increased oxygen tensions. Although cells grown under oxic condition contained higher level of SOD, these exhibited a lower survival after oxic irradiation (Fig. 1A), in other words, a little larger value of OER (Table I). The similar finding has

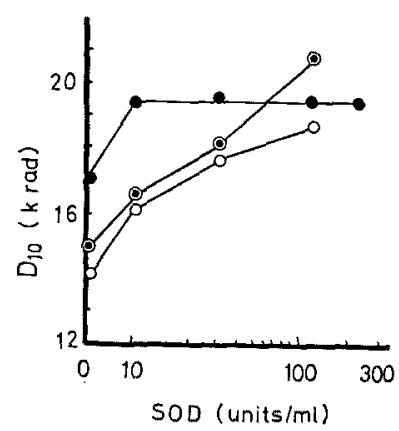

FIG. 2. Effect of SOD Concentration on $\mathrm{D}_{10}{ }^{*}$ of E. coli Cells Irradiated under Normal Air.

Growth conditions of $E$. coli W3623 his were as for Fig. 1. Irradiation was conducted in normal atmospheric condition. Symbols; $\boldsymbol{\bullet}$, cells grown in $\mathrm{N}_{2}$; $\odot$, grown in normal air; $\mathrm{O}$, grown in $\mathrm{O}_{2}$.

* Dose for $10 \%$ inactivation, calculated from the slope of the linear portion of survival curve.

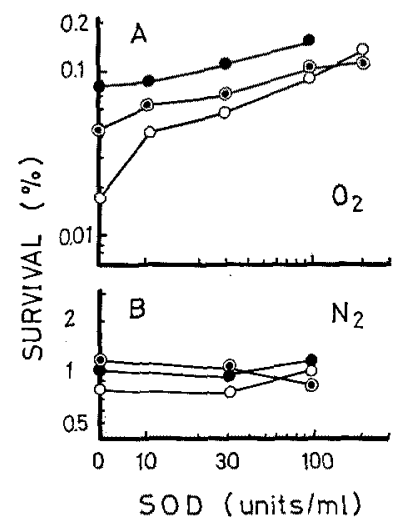

FIG. 3. Effect of SOD Concentration on Survival of E. coli Cells Irradiated under Oxic (A) and Anoxic (B) Conditions.

SOD was added externally to cell suspension. Irradiation dose at $4 \times 10^{4} \mathrm{rad}$ was applied. Other conditions were as for Fig. 1 . Symbols; 0 , cells grown in $\mathrm{N}_{2} ; \odot$, grown in normal air; $\mathrm{O}$, grown in $\mathrm{O}_{2}$.

been reported by Goscin and Fridovich. ${ }^{53}$

\section{Radioprotective effect of $S O D$}

When SOD existed in $E$. coli suspension during irradiation under normal atmosphere, the survival of each cell sample increased according to the amount of added SOD, especially, aerobically grown cells, as shown in Fig. 2. This protective effect of SOD on the oxygen enhanced lethality of radiation was more 
clearly demonstrated by a comparison between oxic and anoxic irradiations as depicted in Fig. $3 \mathrm{~A}$ and $\mathrm{B}$, respectively. In the oxic irradiation under 1 atm of $\mathrm{O}_{2}(\mathrm{~A})$, all three cell samples which were different from one another regarding growth condition accepted benefit in survival depending upon an added SOD concentration. Especially, the effect of the initial addition of SOD in low concentration as $10 \mathrm{U} / \mathrm{ml}$ was remarkable. On the contrary, in the anoxic irradiation under $1 \mathrm{~atm}$ of $\mathrm{N}_{2}$ (B), no significant difference among three cell samples was found. These results unequivocally indicated that the extracellular existence of SOD, a very specific and efficient scavenger for $\mathrm{O}_{2}^{-}$, can rescue bacterial cells from the oxygen enhanced lethal effect. In other words, $\mathrm{O}_{2}^{-}$which is predominantly generated in the aerobic irradiation acts directly or indirectly as a toxic agent.

However, the addition of SOD to a bacterial suspension could not completely protect cells from the oxygen enhanced lethal effect. When $200 \mathrm{U} / \mathrm{ml}$ of SOD was added externally, OER was reduced from 2.0 to 1.5 in cells grown under $1 \mathrm{~atm}$ of $\mathrm{O}_{2}$. With the others the value of $1.4 \sim 1.5$ were obtained by the addition of SOD. It is unlikely that SOD more than $200 \mathrm{U} / \mathrm{ml}$ can completely protect cells from oxygen effect, since the survival value in each sample became to be saturated with the increase of SOD concentration.

\section{Effect of catalase}

The effect of catalase added to E. coli W3623 his $^{-}$cell suspension was examined in oxic irradiation. Catalase in concentration of 200 $\mathrm{U} / \mathrm{ml}$ increased the survival of cells grown anaerobically to $140 \%$ but not that of cells grown aerobically, in which the survival was rather depressed to $85 \%$ as shown in Fig. 4. Catalase in higher concentration than $200 / \mathrm{ml}$ acted like a radiosensitizer in all cases.

\section{Oxygen effect in $\lambda$ phage $D N A$}

The transfecting ability of $\lambda$ phage DNA irradiated under $1 \mathrm{~atm}$ of $\mathrm{O}_{2}$ or $1 \mathrm{~atm}$ of $\mathrm{N}_{2}$ was examined. The results are shown in

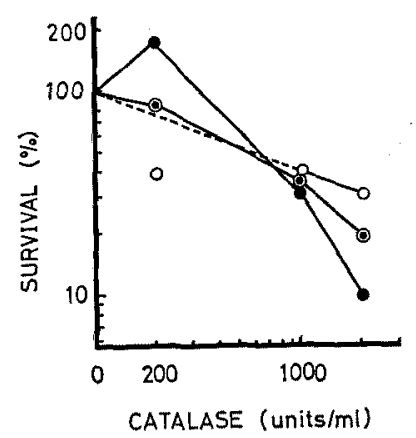

Fig. 4. Effect of Catalase Concentration on Survival of E. coli Cells Irradiated under Oxic Condition. Catalase was added externally to cell suspension. Irradiation at $7 \times 10^{4}$ rad was applied under 1 atm of $\mathrm{O}_{2}$. Other conditions were as for Fig. 1. Symbols; $\boldsymbol{0}$, cells grown in $\mathrm{N}_{2} ; \odot$, grown in normal air; 0 , grown in $\mathrm{O}_{2}$.

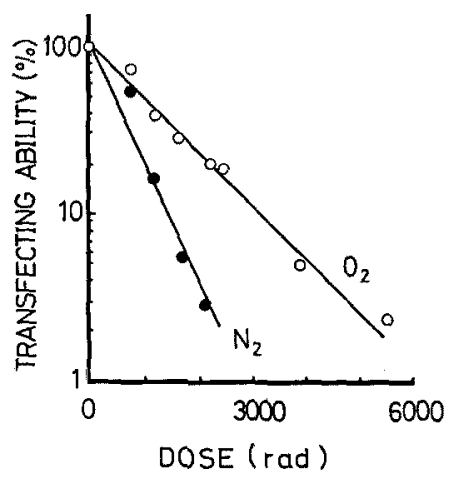

Frg. 5. Transfecting Ability of $\lambda$ Phase DNA Irradiated under Oxic or Anoxic Condition.

$\lambda$ phage DNA solution $(5 \mu \mathrm{g} / \mathrm{ml})$ was irradiated under $1 \mathrm{~atm}$ of $\mathrm{O}_{2}$ or $1 \mathrm{~atm}$ of $\mathrm{N}_{2}$. Details are in Materials AND METHoos. Symbols; 0 , irradiated in $\mathrm{N}_{2}$; $\mathrm{O}$, in $\mathrm{O}_{2}$.

Fig. 5. Both curves of dose versus transfecting ability are linear in semi-logarithmic plotting. Higher radiosensitivity was found in anoxic irradiation than in the oxic. Reverse oxygen effect, i.e. the value of OER is less than 1 was recognized. The sensitizing effect of oxygen on viruses or DNAs is not well established. The reason of this phenomenon, reverse oxygen effect, is quite unclear.

Effect of SOD in irradiation of $\lambda$ phage $D N A$ Although reverse oxygen effect was recogni- 


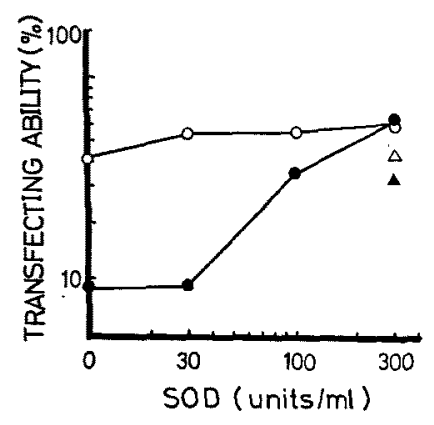

Fig. 6. Effect of SOD Concentration on Transfecting Ability of $\lambda$ Phage DNA.

$\lambda$ phage DNA solution $(2.5 \mu \mathrm{g} / \mathrm{ml})$ was irradiated at $1.5 \times 10^{3} \mathrm{rad}$ under $1 \mathrm{~atm}$ of $\mathrm{O}_{2}$ or $1 \mathrm{~atm}$ of $\mathrm{N}_{2}$. SOD was added into DNA solution. The effect of autoclaved SOD are also shown in this figure. Symbols; $\boldsymbol{\bullet}$, irradiated in $\mathrm{N}_{2} ; \mathrm{O}$, in $\mathrm{O}_{2} ; \boldsymbol{\Delta}$, autoclaved SOD; irradiated in $\mathrm{N}_{2} ; \triangle$, in $\mathrm{O}_{2}$.

zed in the case of $\lambda$ phage DNA, the effect of added SOD on transfecting ability of DNA in both oxic and anoxic irradiations was examined. As shown in Fig. 6, the transfecting ability of phage DNA increased to some extents in oxic irradiation. For example, SOD in $300 \mathrm{U} / \mathrm{ml}$ improved the ability from 39 to $55 \%$. One-tenth concentration of this, $30 \mathrm{U} / \mathrm{ml}$ of SOD, was fairly enough to get such mitigation. Whereas in the anoxic, SOD in the same concentration was found to have little effect on mitigation. However, in higher SOD concentration than $30 \mathrm{U} / \mathrm{ml}$, transfecting ability of phage DNA suddenly raised up. This effect of SOD was checked with autoclaved SOD. The result as shown by a closed triangle in Fig. 6 indicates that this unexpected effect of SOD was not due to an enzymatic character. The mechanism of this has been still unknown.

\section{DISCUSSION}

The phenomenon reconfirmed here that aerobically grown cells exhibited more susceptibility to the oxygen enhanced lethality than anoxically grown cells is of great interest but the reason still remains in the vague. The reinforced cellular SOD in E. coli W3623 his $^{-}$ could not compensate the oxygen effect like in the case of $E$. coli $\mathrm{B}^{\text {s) }}$ Two assumptions may be taken as follows: 1) $\mathrm{O}_{2}^{-}$is not involved in oxygen effect; 2) cellular SOD level is enough to remove $\mathrm{O}_{2}^{-}$generated internally but not externally. The former is unlikely because growing evidence supports a proposal that $\mathrm{O}_{2}^{-}$is responsible for the major component of the oxygen effect in bacterial cell lethality. ${ }^{7,15,18)}$ The latter has been suggested $^{7,15,16)}$ and is plausible when the further assumption is accompained that oxically grown cells have more sensitive site(s) to $\mathrm{O}_{2}^{-}$and/or its products in their surface layers than anoxically grown cells.

In recent years, SOD is used as a convenient scavenger for $\mathrm{O}_{2}^{-}$, since this specific enzyme causes no harm to the matter investigated, though its further detailed characteristics are still to be arguing. ${ }^{1)}$ The highest concentration of external SOD used here, $200 \mathrm{U} / \mathrm{ml}$, is a physiologically reasonable one, because a rough estimation reveals that this SOD level is fairly equal to the intracellular one which is reinforced by induction during oxic growth of cell.

SOD is induced by increased oxygen ten$\operatorname{sion}^{2,3)}$ but it was reported that this was not true in E. coli $\mathrm{K}-12 .^{4)} \quad$ E. coli $\mathrm{W} 3623$ his $^{-}$, one of the derivatives of $E$. coli $\mathrm{K}-12,{ }^{17}$ ) had the inducible character of SOD as is indicated here. Both strains of E. coli W3623 his ${ }^{-}$and E. coli B had SOD of another type besides well-known Mn-SOD and Fe-SOD (Yano and Nishie, in preparation). During the preparation of this manuscript, Hassan and Fridovich reported the third SOD and the inducible character of Mn-SOD in E. coli $\mathrm{K}-12^{18}$ which accord with our results. The third SOD is located in the cell matrix. ${ }^{19}$,

Oxygen induced SODs are a Mn-containing enzyme and the third enzyme. ${ }^{2,19}$; Both exist in cell matrix. ${ }^{19}$ A Fe-containing enzyme is not induced by oxygen, but rather, by nutritional means. ${ }^{16,20)}$ The latter was believed to exist in periplasm and to scavenge $\mathrm{O}_{2}^{-}$generated in the proximity of periplasm and, presumably, $\mathrm{O}_{2}^{-}$invading from outside cell. ${ }^{20}$ Very recently, the intracellular localization of 
the SODs is reevaluated and Fe-SOD is recognized as a matrix enzyme like the others. ${ }^{10}$ ) Oberley and his colleagues reported that nutritionally induced $\mathrm{Fe}$-SOD can protect cells from the oxygen effect in some degrees. ${ }^{163}$ Our experiments was conducted with a single culture medium but under three different oxygen tensions during the growth of bacteria.

Ionizing radiation which has tremendously penetrating ability can cause the event wherever ionizing spur has passed through. Considering the concentration of dissolved oxygen, it is likely that $\mathrm{O}_{2}^{-}$generates more densely outside cell than inside. Exterally added SOD, which should stay outside cell and could not enter inside because of its high molecular size, can remove $\mathrm{O}_{2}^{-}$generated outside. Iodoacetamine and cysteamine are known as a radiosensitizer and a radioprotector, respectively, but these are incapable of penetrating into cell through surface layers even though these have low molecular sizes. ${ }^{21}$,

Recently, the radioprotective effect of catalase is demonstrated in replicative form of $\phi \mathrm{X} 174 \mathrm{DNA}^{22)}$ phage PM2 $\mathrm{DNA}^{23)}$ and $E$, coli $\mathrm{B}^{15)}$ in aerobic irradiation. Misra and Fridovich reach a conclusion that the oxygen enhancement was due to the production of $\mathrm{O}_{2}^{-}$ and $\mathrm{H}_{2} \mathrm{O}_{2}$ in the suspending medium followed by a secondary production of $\mathrm{OH}^{*}$ and perhaps of singlet oxygen, ${ }^{1} \mathrm{O}_{2} \cdot{ }^{15}$ ) In this study, added catalase was found to act as a radiosensitizer, possibly due to its high concentration as compared with that of $\mathrm{H}_{2} \mathrm{O}_{2}$ generated during irradiation. The sensitizing effect of catalase might be due to the peroxidation of some constituents in the outer surface layers of a cell, since catalase does not seem to enter inside cell as well as SOD. Thus, an assumption again arises that the primary target in oxygen effect may be some sites existing in the outer structure of cell. It is noteworthy that aerobically grown cells but not anaerobically grown cells were susceptible when $200 \mathrm{U} / \mathrm{ml}$ of catalase was added to the cell suspension to be irradiated (Fig. 4). More detailed investigations should be needed.

The involvement of $\mathrm{O}_{2}^{-}$in oxygen effect had been ignored since the addition of $\mathrm{I}^{-}$, which is a strong scavenger for $\mathrm{OH}$, into $\phi \mathrm{X} 174 \mathrm{DNA}$ suspension mitigates lethality in oxic irradiation so much extents in anoxic irradiation. ${ }^{24}$ Recent studies reveal, as described above, that SOD can mitigate the oxygen effect in both $\phi \mathrm{X} 174$ and PM2 DNAs. ${ }^{22,23)}$ Thus, $\mathrm{O}_{2}^{-}$can damage in vitro DNAs in some extents. The addition of SOD in concentration of $300 \mathrm{U} / \mathrm{ml}$ fairly improved the transfecting ability of $\lambda$ phage DNA (Fig. 6). This finding indicates the toxicity of $\mathrm{O}_{2}^{-}$for DNA in vitro. The decrease of transfecting ability in anoxic irradiation and its mitigation by heat denatured SOD could not be explained now. In the case of $\phi \mathrm{X} 174 \mathrm{DNA}$, the experiment was conducted in the presence of formate, a scavenger for both $\mathrm{OH}^{\cdot}$ and $\mathrm{H}^{\cdot}{ }^{22}$ ) The combination of scavengers could facilitate to elucidate a whole mechanism. However, it can be predicted that the other species such as $\mathrm{OH}^{*}, \mathrm{H}^{-}$and $e_{\mathrm{aq}}^{-}$must be more harmful to DNAs than $\mathrm{O}_{2}^{-}$ even though the toxicity of the latter is established.

The most probable target in the primary event in oxygen effect may be the site(s) other than DNA as already speculated by Alper. ${ }^{25}$. It might be a component(s) containing lipids and it may exist in the outer structure of cell. If this is the case, singlet oxygen, ${ }^{1} \mathrm{O}_{2}$, generated secondarily may be a direct agent to. damage a susceptible component(s). The role of ${ }^{1} \mathrm{O}_{2}$ in the peroxidation of lipids is suggested recent$\mathrm{Iy}^{26)}$ and there is growing evidence that ${ }^{1} \mathrm{O}_{2}$ acts a potentially dangerous role in biological system. ${ }^{27}$ These considerations do not exclude DNA as the secondary target in oxygen effect, since the function of outer structure is still equivocal and a protein in outer membrane that is involved in DNA replication has been demonstrated recently. ${ }^{28)}$

The authors are sincerely indebted to Profs. K. Asada and H. Ozeki, Kyoto University for their invaluable support. The authors are also grateful to The Research Center of Nuclear Science and Technology, The University of Tokyo for allowing them the use of the ${ }^{80} \mathrm{Co}$ irradiator and Mr. S. Katsura for his expert assistance to drive it. This research was 
supported in part by a scientific research grant from the Ministry of Education, Japan.

\section{REFERENCES}

1) I. Fridovich, Ann. Rev. Biochem., 44, 147 (1975).

2) E. M. Gregory and I. Fridovich, J. Bacteriol., 11, 543 (1973).

3) E. M. Gregory and I. Fridovich, ibid., 114, 1193 (1973).

4) E. M. Gregory, S. A. Goscin and I. Fridovich, ibid., 117, 456 (1974).

5) S. A. Goscin and I. Fridovich, Radiat. Res., 56, 565 (1973).

6) A. Hollaender, G. E. Stapleton and F. L. Martin, Nature, 167, 103 (1951).

7) A. Petkau and W. S. Chelack, Int. J. Radiat. Biol., 26, 421 (1974).

8) A. Petkau and W. S. Chelack, Biochim. Biophys. Acta, 433, 445 (1976).

9) T. Niwa, H. Yamaguchi and K. Yano, in "Biochemical and Medical Aspects of Active Oxygen," ed. by O. Hayaishi and K. Asada, Univ. of Tokyo Press, Tokyo, 1977, p. 209.

10) A. D. Aershey, E. Burgi and L. Ingraham, Proc. Natl. Acad. Sci. U.S.A., 49, 748 (1963).

11) M. Mandel and A. Higa, J. Mol. Biol., 53, 159 (1970).

12) A. D. Keiser, ibid., 4, 275 (1962).

13) K. Asada, M. Takahashi and M. Nagate, Agric. Biol. Chem., 38, 471 (1974).
14) J. M. McCord, B. B. Keele Jr. and I. Fridovich, Proc. Natl. Acad. Sci. U.S.A., 68, 1024 (1971).

15) H. P. Misra and I. Fridovich, Arch. Biochem. Biophys., 176, 577 (1976).

16) L. W. Oberley, A. L. Lindgren, S. A. Baker and R. H. Stevens, Radiat. Res., 68, 320 (1976).

17) B. J. Bachmann, Bacteriol. Rev., 36, 525 (1972).

18) H. M. Hassan and I. Fridovich, J. Bacteriol., 129, 1574 (1977).

19) L. Britton and I. Fridovich, ibid, 131, 815 (1977).

20) E. M. Gregory, F. J. Yost and I. Fridovich, ibid., 115, 987 (1973).

21) P. Alexander, C. J. Dean, C. D. Hamilton, J. T. Lett and G. Parkins, in "Cellular Radiation Biology," Papers 8th Ann. Sym. on Fundamental Cancer Res. 1964, The Williams and Wilkins Co. 1965, p. 241.

22) J. J. van Hemmen and W. J. A. Meuling, Biochim. Biophys. Acta, 402, 133 (1975).

23) A. R. Morgan, R. L. Cone and T. M. Elgert, Nucleic Acid Res., 3, 1139 (1976).

24) J. Blok, I. H. Luthjens and A. L. M. Roos, Radiat. Res., 30, 468 (1967).

25) T. Alper, in "Biophysical Aspects of Radiation Quality," Proc. of IAEA Symp., IAEA, Vienna, 1971, p. 171, IAEA-SM-145/1.

26) E. W. Kellogg III and I. Fridovich, J. Biol. Chem., 250, 8812 (1975).

27) N. Krinsky, Trends in Biochem. Sci.. 2, 35 (1977).

28) L. J. Gudas, R. James and A. B. Pardee, J. Biol. Chem., 251, 3470 (1976). 